\section{Response to: 'Clarification regarding the statement of the association between the recombinant zoster vaccine (RZV) and gout flares' by Didierlaurent et al}

We read with great interest the correspondence from Didierlaurent et $\mathrm{al}^{1}$ regarding our recent report on the association between vaccination and risk of gout flares using a case-crossover design. ${ }^{2}$ In particular, we appreciate the clarification that the authors provided regarding the unsolicited adverse events reported during the 30 days after each vaccination, including episodes of gout, with incident gout cases surpassing reports of recurrent gout flares. While this is a notable difference from our online case-crossover study which included only patients with known gout and assessed for recurrent gout flares, this raises the intriguing possibility of the vaccine 'unmasking' gout in susceptible individuals, whether mediated by the effect of the vaccine adjuvant on the inflammasome pathway or another mechanism. It is well-recognised that patients with incident gout have a history of chronic hyperuricemia that leads to the asymptomatic deposition of monosodium urate (MSU) crystals in and around joints long before the first clinically apparent flare of gout. ${ }^{3}$ For example, studies of patients with asymptomatic hyperuricaemia, a prerequisite condition for the eventual development of gout, have demonstrated that approximately $25 \%$ of patients have evidence of asymptomatic MSU deposits when assessed with advanced imaging techniques such as ultrasound or dual-energy $\mathrm{CT}^{4}{ }^{4}$ Thus, while the results of our study may not be directly applicable to these patients who reported incident gout after recombinant zoster vaccine vaccination, the available data to date collectively call for future studies including patients with and without existing gout.

We agree with the authors that the hypothesised mechanisms underlying the potential association between vaccination and gout flares involving the activation of the inflammasome are derived from in vitro studies ${ }^{56}$ and has not been definitively demonstrated in vivo. The authors also raise the intriguing possibility of the risk of gout flares being mediated by serum urate change, similar to other known triggers for gout flares such as diuretics ${ }^{78}$ and alcohol use, ${ }^{9-11}$ as a result of the release of DNA material by dying innate cells after they have been recruited at the site of injection. ${ }^{12}$ Serial measurements of serum urate before and after vaccination can be a readily implementable first step to further elucidate this possibility.

Finally, we reiterate that the benefits of vaccinations far outweigh the possible small risks of gout flares.

\footnotetext{
Chio Yokose $\odot 1^{1,2}$ Hyon Choi ${ }^{1,2,3}$

${ }^{1}$ Division of Rheumatology, Allergy and Immunology, Department of Medicine, Massachusetts General Hospital, Boston, Massachusetts, USA

${ }^{2}$ Clinical Epidemiology Program, Mongan Institute, Massachusetts General Hospital, Boston, MA, USA

${ }^{3}$ Arthritis Research Canada, Richmond, British Columbia, Canada
}

Correspondence to Dr Hyon Choi, Division of Rheumatology, Allergy and Immunology, Department of Medicine, Massachusetts General Hospital, Boston, MA, United States; HCHOI@mgh.harvard.edu
Handling editor Josef S Smolen

Contributors All authors contributed equally to this work.

Funding CY is supported by the National Institutes of Health Ruth L. Kirschstein Institutional National Research Service Award [T32-AR-007258]. HC is supported by the National Institutes of Health [P50 AR060772].

Competing interests $\mathrm{CY}$ has no disclosures. $\mathrm{HC}$ reports consulting for Ironwood, Selecta, Horizon, Takeda, Kowa and Vaxart; research support from Ironwood and Horizon.

Patient consent for publication Not required.

Provenance and peer review Commissioned; internally peer reviewed.

(c) Author(s) (or their employer(s)) 2019. No commercial re-use. See rights and permissions. Published by BMJ.

\section{Check for updates}

To cite Yokose C, Choi H. Ann Rheum Dis Epub ahead of print: [please include Day Month Year]. doi:10.1136/annrheumdis-2019-216670

Received 5 December 2019

Accepted 6 December 2019

\section{S Linked}

- http://dx.doi.org/10.1136/annrheumdis-2019-216639

Ann Rheum Dis 2019;0:1. doi:10.1136/annrheumdis-2019-216670

\section{ORCID iD}

Chio Yokose http://orcid.org/0000-0001-7557-3303

\section{REFERENCES}

1 Didierlaurent AM, Desssart C, Cunningham AL. Clarification regarding the statement of the association between the recombinant zoster vaccine (RZV) and gout flares. Ann Rheum Dis 2019. doi:10.1136/annrheumdis-2019-216639. [Epub ahead of print: 02 Dec 2019].

2 Yokose C, McCormick N, Chen C, et al. Risk of gout flares after vaccination: a prospective case cross-over study. Ann Rheum Dis 2019;78:1601-4.

3 Campion EW, Glynn RJ, DeLabry LO. Asymptomatic hyperuricemia. risks and consequences in the normative aging study. Am J Med 1987;82:421-6.

4 Dalbeth $\mathrm{N}$, House ME, Aati $\mathrm{O}$, et al. Urate crystal deposition in asymptomatic hyperuricaemia and symptomatic gout: a dual energy CT study. Ann Rheum Dis 2015;74:908-11.

5 Eisenbarth SC, Colegio OR, O'Connor W, et al. Crucial role for the NALP3 inflammasome in the immunostimulatory properties of aluminium adjuvants. Nature 2008;453:1122-6.

6 Franchi L, Núñez G. The NLRP3 inflammasome is critical for aluminium hydroxidemediated IL-1 beta secretion but dispensable for adjuvant activity. Eur J Immunol 2008:38:2085-9.

7 Kahn AM. Effect of diuretics on the renal handling of urate. Semin Nephrol 1988:8:305-14.

8 Choi HK, Atkinson K, Karlson EW, et al. Obesity, weight change, hypertension, diuretic use, and risk of gout in men: the health professionals follow-up study. Arch Intern Med 2005;165:742-8.

9 Puig JG, Fox IH. Ethanol-Induced activation of adenine nucleotide turnover. Evidence for a role of acetate. J Clin Invest 1984;74:936-41.

10 Lieber CS, Jones DP, Losowsky MS, et al. Interrelation of uric acid and ethanol metabolism in man. J Clin Invest 1962;41:1863-70.

11 Choi HK, Atkinson K, Karlson EW, et al. Alcohol intake and risk of incident gout in men: a prospective study. Lancet 2004;363:1277-81.

12 Kool M, Soullié T, van Nimwegen M, et al. Alum adjuvant boosts adaptive immunity by inducing uric acid and activating inflammatory dendritic cells. J Exp Med 2008;205:869-82. 